\title{
Synthesis of thienoselenadiazole-containing conjugated copolymers and their application in polymer solar cells
}

\author{
Xingxing Shen ${ }^{1,2}$, Shan $\mathrm{Chen}^{2}$, Zuo Xiao ${ }^{2}$, Qiqun $\mathrm{Zuo}^{3}$, Yiwang $\mathrm{Chen}^{1}$ and Liming Ding ${ }^{2}$ \\ Polymer Journal (2012) 44, 978-981; doi:10.1038/pj.2012.33; published online 28 March 2012 \\ Keywords: bandgaps; conjugated polymers; HOMO and LUMO levels; polymer solar cells; thienoselenadiazole
}

\begin{abstract}
INTRODUCTION
In recent years, polymer solar cells (PSCs) have attracted great attention due to the energy crisis all over the world. Compared with inorganic solar cells, PSCs have many advantages, such as light weight, solution processability, mechanical flexibility and low cost. ${ }^{1}$ The stateof-the-art of PSCs are based on a fullerene-derivative acceptor, such as [6,6]-phenyl-C61-butyric acid methyl ester $\left(\mathrm{PC}_{61} \mathrm{BM}\right)$ or $[6,6]$ phenyl-C71-butyric acid methyl ester $\left(\mathrm{PC}_{71} \mathrm{BM}\right)$, and a conjugated polymer donor, such as poly(3-hexylthiophene) (P3HT). ${ }^{2}$ Power conversion efficiency (PCE) of $4-5 \%$ has been achieved for P3HT/ PCBM solar cells. ${ }^{3}$ To obtain high-performance PSCs, a variety of low-bandgap conjugated polymers have been synthesized through donor-acceptor (D-A) copolymerization. ${ }^{4,5}$ A number of electronrich heterocycles, such as benzodithiophene (BDT), ${ }^{6}$ dithieno[3,2$\mathrm{b}: 2^{\prime}, 3^{\prime}$-d] silole (DTS $)^{7}$ and indacenodithiophene, ${ }^{8}$ have been widely used as donor units, whereas benzothiadiazole, ${ }^{9}$ thieno[3,4-c]pyrrole-4,6-dione $^{10}$ and diketopyrrolo[3,4-c]-pyrrole-1,4-dione ${ }^{11}$ have been used as acceptor units. Recently, remarkable progress has been made by using a new copolymer, PBDTTT-CF, yielding a high PCE up to $7.73 \% .{ }^{12}$ To further improve the device performance, some heavy-atom-containing heterocycles, such as Se- and Ge-containing heterocycles, have also been explored for developing novel D-A copolymers. ${ }^{13,14}$ The influence of the selenium atom on the electron distribution and the charge transport property has been investigated..$^{15}$ Selenium shows a stronger heteroaromatic interaction than sulfur, and it may enhance the inter-chain interaction and free charge carrier transportation. ${ }^{16}$ To the best of our knowledge, the novel selenium-heterocycle thienoselenadiazole, has never been synthesized and investigated as the building block for conjugated polymers. In this work, we report for the first time the synthesis of a thienoselenadiazole derivative 4,6-Bis $\left(4^{\prime}\right.$-hexylthiophen-2' yl)thieno[3,4-c][1,2,5] selenadiazole (DTTSe) through the con-
\end{abstract}

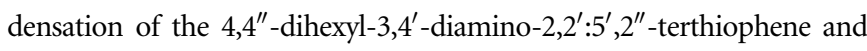
$\mathrm{SeO}_{2}$. Furthermore, we synthesized two new Se-containing conjugated copolymers PBDTDTTSe and PDTSDTTSe by copolymerization of DTTSe with BDT and DTS. The optical, electrochemical and photovoltaic properties of the polymers were investigated.

\section{EXPERIMENTAL PROCEDURE}

\section{Synthesis and characterization}

${ }^{1} \mathrm{H}$ and ${ }^{13} \mathrm{C}$ NMR spectra were measured on a Bruker Avance-400 spectrometer (Ettlingen, Germany). Mass spectra were measured by an Auto Flex III (MALDI-TOF) spectrometer (Bremen, Germany). The molecular weight of the polymers was measured by gel permeation chromatography, and polystyrene was used as a standard. Thermogravimetric analysis was performed on a Perkin-Elmer Diamond TG/DTA instrument (Waltham, MA, USA). Absorption spectra were measured on a SHIMADZU UV-1800 spectrophotometer (Kyoto, Japan). Cyclic voltammetry was conducted in a $0.1 \mathrm{moll}^{-1}$ tetrabutylammonium hexafluorophosphate $\left(\mathrm{Bu}_{4} \mathrm{NPF}_{6}\right)$ acetonitrile solution using a glassy-carbon electrode coated with the polymer film as the working electrode, a Pt wire as the counter electrode and an $\mathrm{Ag} / \mathrm{Ag}^{+}$electrode as the reference electrode. All potentials were corrected against $\mathrm{Fc} / \mathrm{Fc}^{+}$. Tetrahydrofuran (THF) and toluene were dried over $\mathrm{Na}$ /benzophenone and freshly distilled before use. 2,5-Dibromo-3,4-dinitrothiophene (1), ${ }^{17}$ 2,6-Bis(trimethyltin)-4,8-bis(2-ethyl hexoxy)benzo[1,2-b:3,4-b]dithiophene (6), ${ }^{18}$ and 4,4'-Bis(2-ethylhexyl)-5,5'bis(trimethyltin)dithieno[3,2-b:2,3'-d] silole $(7)^{18}$ were synthesized according to the methods reported in the literature. 4,4'-Bis(2-ethylhexyl)-5, $5^{\prime}$ dibromodithieno[3,2-b:2', $3^{\prime}$-d] silole was purchased from Solarmer Materials (Beijing, China). The synthetic routes for the monomers and polymers are shown in Figure 1. The detailed synthetic procedures for 2, 3, 5 and PDTSDTTSe are described in the Supplementary Information. The detailed synthetic procedures for $\mathbf{4}$ and PBDTDTTSe are as follows: 4,6-Bis $\left(4^{\prime}\right.$-hexylthiophen-2' ${ }^{\prime}$-yl)thieno[3,4-c] $[1,2,5]$ selenadiazole $(4)^{19}$ Compound 3 $(0.5 \mathrm{~g}, 1.1 \mathrm{mmol})$ was dissolved in anhydrous tetrahydrofuran $(20 \mathrm{ml})$ under $\mathrm{N}_{2}$. To the solution was added $\mathrm{SeO}_{2}(0.4 \mathrm{~g}, 3.6 \mathrm{mmol})$. The mixture was then refluxed for $12 \mathrm{~h}$. The reaction xmixture was cooled to room temperature,

${ }^{1}$ Institute of Polymers, Nanchang University, Nanchang, China; ${ }^{2}$ National Center for Nanoscience and Technology, Beijing, China and ${ }^{3}$ Jiahong Optoelectronics, Suzhou, China Correspondence: Dr L Ding, National Center for Nanoscience and Technology, No. 11 Beiyitiao, Zhongguancun, Beijing 100190, China.

E-mail: OPV.CHINA@yahoo.com.

or Dr Y Chen, Institute of Polymers, Nanchang University, Xuefu Road 999, Nanchang 330031, China.

E-mail: ywchen@ncu.edu.cn

Received 24 December 2011; revised 9 February 2012; accepted 10 February 2012; published online 28 March 2012 

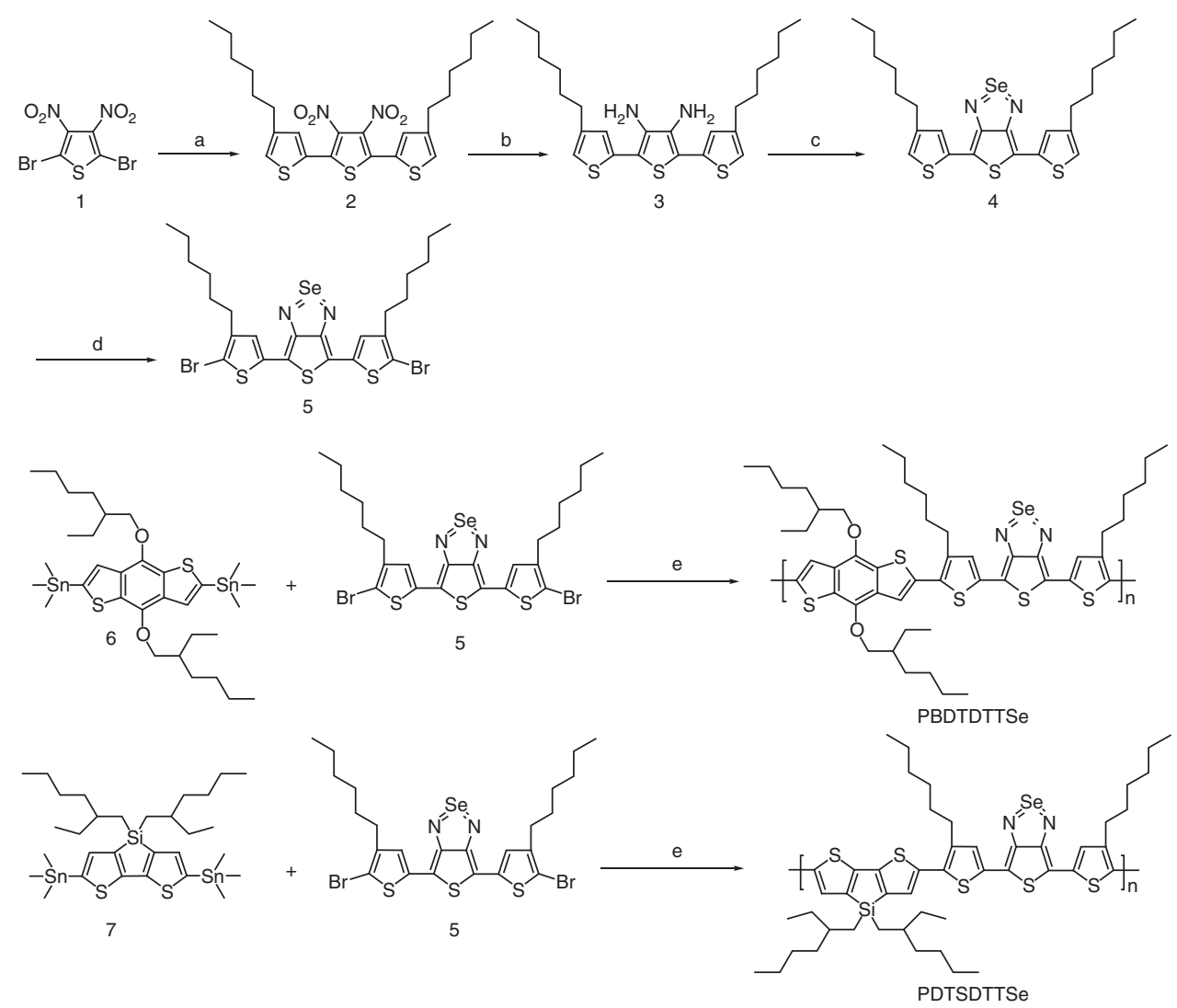

Figure 1 Synthetic routes for the monomers and copolymers. Reagents and conditions: (a) 3-hexyl-5-tributylstannyl-thiophene, THF, $\mathrm{Pd}(\mathrm{PPh})_{4}, 24 \mathrm{~h}$; (b) $\mathrm{SnCl}_{2}, \mathrm{HCl}, \mathrm{EtOH}, 18 \mathrm{~h}$; (c) $\mathrm{SeO}_{2}, \mathrm{THF}$, reflux for $12 \mathrm{~h}$, under $\mathrm{N}_{2}$; (d) $\mathrm{Br}_{2}, \mathrm{AcOH}, 40^{\circ} \mathrm{C}, 36 \mathrm{~h}$ and (e) $\left.\mathrm{Pd}_{(} \mathrm{PPh}_{3}\right)_{4}$, toluene, under argon.

filtered and dried over anhydrous $\mathrm{MgSO}_{4}$. After removal of the solvent by rotary evaporation, the residue was purified by silica gel column chromatography with petroleum ether/chloroform (1:1) as the eluent. The product 4 was obtained as a sticky dark red oil $(0.33 \mathrm{~g}$, yield: $58 \%)$. ${ }^{1} \mathrm{H}$ NMR $\left(\mathrm{CDCl}_{3}, 400 \mathrm{MHz}\right), \delta$ (p.p.m.): 7.78 (d, 2H), $7.43(\mathrm{~d}, 2 \mathrm{H}), 2.59-2.65$ (m, 4H), $1.56-1.65(\mathrm{~m}, 4 \mathrm{H}), 1.26-1.34(\mathrm{~m}, 12 \mathrm{H}), 0.88(\mathrm{t}, 6 \mathrm{H}) .{ }^{13} \mathrm{C}$ NMR $\left(\mathrm{CDCl}_{3}\right.$, $100 \mathrm{MHz}$ ), $\delta$ (p.p.m.): 178.57, 163.22, 144.01, 139.82, 136.55, 131.06, 30.55, 29.32, 29.19, 27.84, 21.54, 13.06. MALDI-TOF-MS for $\mathrm{C}_{24} \mathrm{H}_{30} \mathrm{~N}_{2} \mathrm{~S}_{3} \mathrm{Se}\left[\mathrm{M}+\mathrm{Li}^{+}\right]$: 529.1. Poly $\left\{4,8\right.$-diethylhexyloxybenzo[1,2-b;3,4-b]dithiophene-alt-4,6-Bis $\left(4^{\prime}\right.$-hexyl thiophen- $2^{\prime}$-yl)thieno[3,4-c] [1,2,5]selenadiazole\} (PBDTDTTSe). To a solution of $5(120 \mathrm{mg}, 0.18 \mathrm{mmol})$ and $\mathbf{6}(136 \mathrm{mg}, 0.18 \mathrm{mmol})$ in toluene $(20 \mathrm{ml})$ was added $\mathrm{Pd}\left(\mathrm{PPh}_{3}\right)_{4}(11 \mathrm{mg}, 0.009 \mathrm{mmol}$, ) under Ar. The reaction mixture was then heated to reflux for $12 \mathrm{~h}$. The mixture was cooled to room temperature and precipitated by addition of methanol $(200 \mathrm{ml})$. The solid was filtered and subjected to a Soxhlet extractor. The solid was successively extracted with methanol, hexane, and chloroform. The polymer was recovered from the chloroform fraction as a red solid $(110 \mathrm{mg}$, yield $63 \%) .{ }^{1} \mathrm{H} \mathrm{NMR}\left(\mathrm{CDCl}_{3}\right.$, $400 \mathrm{MHz}), \delta$ (p.p.m.): 7.84 (s, 2H), 7.66 (s, 2H), 4.23 (d, 4H), 2.85 (d, 4H), 1.26-1.88 (m, 34H), 0.83-1.09 (m, 18H). Poly $\left\{4,4^{\prime}\right.$-bis(2-ethylhexyl)dithieno [3,2-b:2', $3^{\prime}$-d] silole-alt-4,6-bis (4' -hexylthiophen-2'-yl)thieno[3,4-c] [1,2,5] selena diazole\} (PDTSDTTSe) PDTSDTTSe was synthesized according to the same procedure as PBDTDTTSe, using monomer $7(164 \mathrm{mg}, 0.22 \mathrm{mmol})$ and 5 $(150 \mathrm{mg}, 0.22 \mathrm{mmol})$ as the starting materials. PDTSDTTSe was obtained as a deep red solid (50 mg, yield: $24 \%) .{ }^{1} \mathrm{H}$ NMR $\left(\mathrm{CDCl}_{3}, 400 \mathrm{MHz}\right), \delta$ (p.p.m.): $7.71(\mathrm{~s}, 2 \mathrm{H}), 7.23(\mathrm{~s}, 2 \mathrm{H}), 2.74(\mathrm{~d}, 4 \mathrm{H}), 1.60(\mathrm{~d}, 4 \mathrm{H}), 0.64-1.45(\mathrm{~m}, 52 \mathrm{H})$. Figures S1-S5 in Supplementary Information show the NMR spectra for compound 2, 3, 4, 5, PBDTDTTSe, and PDTSDTTSe. Mass spectrum for compound 4 can be found in Supplementary Information.

\section{Fabrication and characterization of solar cells}

Solar cells with the typical structure of ITO/PEDOT:PSS/Polymer: $\mathrm{PC}_{71} \mathrm{BM}$ $(1: 1) / \mathrm{Ca} / \mathrm{Al}$ were fabricated under similar conditions as follows: The ITO glass was cleaned by sequential ultrasonic treatment in detergent, deionized water, acetone and isopropanol, and then treated in an ultraviolet-ozone chamber for $15 \mathrm{~min}$. Then PEDOT:PSS (poly (3,4-ethylene dioxythiophene):poly(styrene sulfonate)) (Clevios P Al 4083, Leverkusen, Germany) was filtered through a $0.45 \mu \mathrm{m}$ filter and spin coated at 4000 r.p.m. for $30 \mathrm{~s}$ on the ITO glass. Subsequently, the PEDOT: PSS film was baked at $140^{\circ} \mathrm{C}$ for $10 \mathrm{~min}$ in the air. The blend solution of PBDTDTTSe or PSBTDTTSe and $\mathrm{PC}_{71} \mathrm{BM}$ in 1,2dichlorobenzene (o-DCB) $\left(12 \mathrm{mg} \mathrm{ml}^{-1}\right)$ was then spin coated (800 r.p.m. for $60 \mathrm{~s})$ on top of the PEDOT:PSS layer. Thermal annealing was then performed at $110^{\circ} \mathrm{C}$ for $10 \mathrm{~min}$. The devices were completed by thermal evaporation of $\mathrm{Ca}(10 \mathrm{~nm}) / \mathrm{Al}(100 \mathrm{~nm})$ as cathodes with an area of $7.57 \mathrm{~mm}^{2}$ in a pressure of ca. $10^{-6} \mathrm{~Pa}$. Device characterization was done in the air under simulated AM1.5G irradiation $\left(86 \mathrm{~mW} \mathrm{~cm}^{-2}\right)$ using a xenon-lamp-based solar simulator (Newport, North Billerica, MA, USA) calibrated with a standard single-crystal Si photovoltaic cell.

\section{RESULTS AND DISCUSSION}

The general synthetic routes for the monomers and copolymers are outlined in Figure 1. The key annulation reaction for thienoselenadiazole was realized by condensation of thiophene diamine 3 and $\mathrm{SeO}_{2}$ for the first time. The thienoselenadiazole 4 was obtained in $58 \%$ yield and was characterized by spectroscopic methods. The MALDI-TOF mass spectrum of 4 afforded the expected molecular ion peak plus one lithium ion. The numbers and the intensity of the isotope peaks of the spectrum are also in good agreement with that of the simulated one (see Supplementary Information). The thienoselenadiazole-containing copolymers were synthesized by the Stille coupling reaction. The two copolymers PBDTDTTSe and PDTSDTTSe have good solubility in common organic solvents, such as chloroform and 1,2-dichlorobenzene. Molecular weights determined by gel permeation chromatography are $1.87 \times 10^{4}$ and 
$1.32 \times 10^{4}$ for PBDTDTTSe and PDTSDTTSe, respectively. The PDI for PBDTDTTSe and PDTSDTTSe are 1.82 and 1.49, respectively.

Thermogravimetric analysis results show that the decomposition temperatures for PBDTDTTSe and PDTSDTTSe are 317 and $224^{\circ} \mathrm{C}$, respectively. In comparison to other D-A-conjugated polymers, the decomposition temperatures for PBDTDTTSe and PDTSDTTSe are relatively low, which might be due to the instability of the thienoselenadiazole heterocycle. Even so, the thermal stability of the two copolymers is good enough for solar cell applications.

The optical properties of the polymers were investigated by UV-vis absorption spectroscopy in chloroform solutions and in films. As shown in Figure 2, the absorption spectra of PBDTDTTSe in solution and in film both show two absorption peaks, located at $\sim 400$ and $\sim 480 \mathrm{~nm}$, respectively. On the contrary, the spectra of PDTSDTTSe show only one peak at $\sim 500 \mathrm{~nm}$ in both solution and film. The absorption maximum for PDTSDTTSe is more red-shifted in comparison with PBDTDTTSe due to the stronger electron-donating ability of the DTS moiety. The spectra of the two polymer films are broader than that of their solutions due to the aggregation of the polymer chains in the solid state. The absorption edges of PBDTDTTSe and PDTSDTTSe films are at 609 and $620 \mathrm{~nm}$, suggesting bandgaps of 2.04 and $2.00 \mathrm{eV}$, respectively.

Cyclic voltammetry was carried out for estimating the HOMO (highest occupied molecular orbital) levels, the LUMO (lowest unoccupied molecular orbital) levels and the bandgaps of the polymers, according to the following equations: ${ }^{20}$

$$
\begin{aligned}
& E_{\mathrm{HOMO}}=-e\left(E_{\mathrm{ox}}^{\mathrm{on}}+4.8\right)(\mathrm{eV}) \\
& E_{\mathrm{LUMO}}=-e\left(E_{\mathrm{red}}^{\mathrm{on}}+4.8\right)(\mathrm{eV}) \\
& E_{\mathrm{g}}^{\mathrm{ec}}=E_{\mathrm{LUMO}}-E_{\mathrm{HOMO}}(\mathrm{eV})
\end{aligned}
$$

The cyclic voltammograms of the two polymers are shown in Figure 3. The electrochemical data are listed in Table 1. The onset reduction potentials $\left(E_{\mathrm{red}}^{\text {on }}\right)$ of PBDTDTTSe and PDTSDTTSe are -1.62 and $-1.51 \mathrm{~V}$, respectively, and the onset oxidation potentials $\left(E_{\mathrm{OX}}^{\mathrm{on}}\right)$ are 0.71 and $0.70 \mathrm{~V}$, respectively. Both polymers exhibit relatively deep HOMO energy levels $(-5.51$ and $-5.5 \mathrm{eV})$ suggesting that they are stable against oxidation and may lead to a high opencircuit voltage $\left(V_{\mathrm{oc}}\right)$ of the solar cells, because $V_{\mathrm{oc}}$ is proportional to the energy difference between the HOMO of the donor and LUMO of the acceptor.

Solar cells with a configuration of ITO/PEDOT:PSS/Polymer: $\mathrm{PC}_{71} \mathrm{BM} / \mathrm{Ca} / \mathrm{Al}$ were fabricated and tested under simulated $\mathrm{AM} 1.5 \mathrm{G}$ irradiation $\left(86 \mathrm{~mW} \mathrm{~cm}^{-2}\right)$. The corresponding open-circuit voltage $\left(V_{\mathrm{oc}}\right)$, short-circuit current density $\left(J_{\mathrm{sc}}\right)$, fill factor and PCE of the cells are listed in Table 2. Cells based on PBDTDTTSe:PC ${ }_{71} \mathrm{BM}$ and PDTSDTTSe:PC ${ }_{71} \mathrm{BM}$ both show high $V_{\mathrm{oc}}(0.78-0.89 \mathrm{~V})$, due to the low-lying HOMO levels of the polymers. However, the high bandgap $(\sim 2.3 \mathrm{eV})$ and moderate light absorption of the polymers lead to very poor $J_{\mathrm{sc}}$, although the $J_{\mathrm{sc}}$ of PDTSDTTSe is slightly better than that of PBDTDTTSe because of better light absorption of PDTSDTTSe. The LUMO levels $(\sim-3.2 \mathrm{eV})$ of both polymers are much higher than that of $\mathrm{PC}_{71} \mathrm{BM}$, which will cause unexpected energy loss in the process of free charge carrier generation. The thicknesses of the active layers for the devices were optimized. $55-60 \mathrm{~nm}$ thick active layers gave the highest PCE of 0.14 and $0.20 \%$ for PBDTDTTSe and PDTSDTTSe devices, respectively.
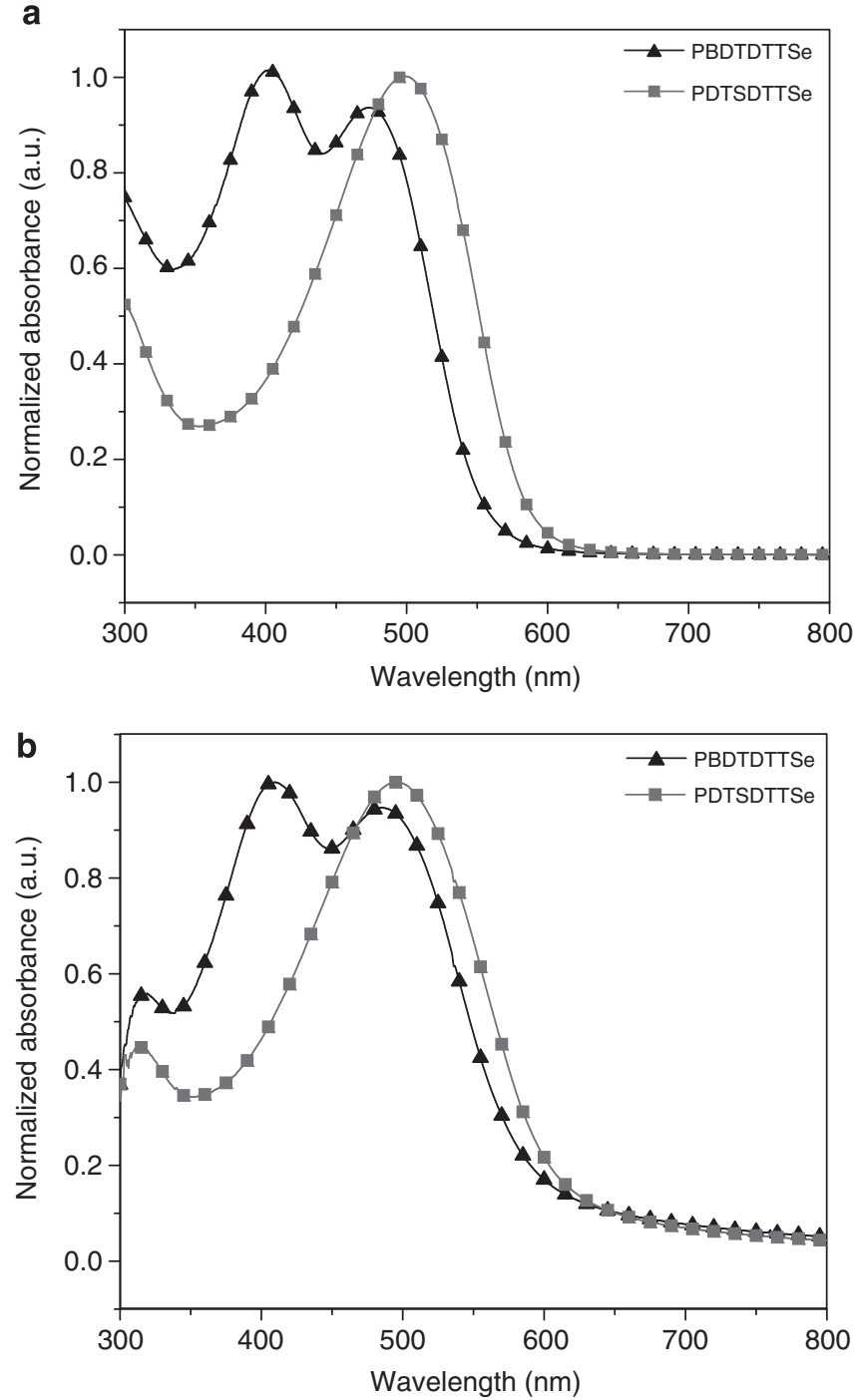

Figure 2 Absorption spectra of the copolymers (a) in solution and (b) in film. A full color version of this figure is available at Polymer Journal online.

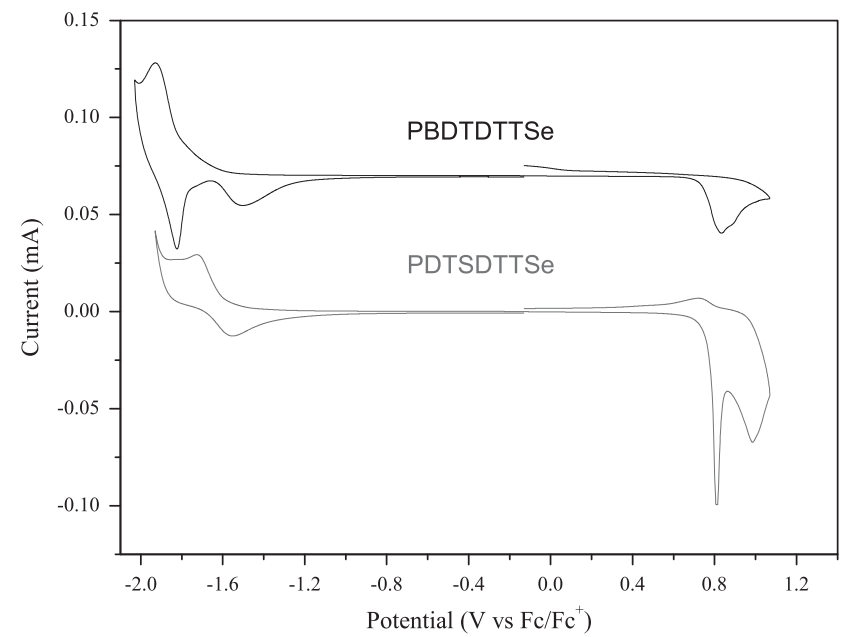

Figure 3 Cyclic voltammograms of the polymer films measured in $\mathrm{CH}_{3} \mathrm{CN}$ containing $0.1 \mathrm{M} \mathrm{Bu}_{4} \mathrm{NPF}_{6}$. A full color version of this figure is available at Polymer Journal online. 
Table 1 Photovoltaic properties of the solar cells based on PBDTDTTSe and PDTSDTTSe under the illumination of AM1.5G $86 \mathrm{~mW} \mathrm{~cm}^{-2}$

\begin{tabular}{|c|c|c|c|c|}
\hline Active layer & $\mathrm{V}_{o c}(V)$ & $\mathrm{J}_{s c}\left(m A c m^{-2}\right)$ & $F F(\%)$ & $P C E(\%)^{a}$ \\
\hline PBDTDTTSe:PC ${ }_{71} \mathrm{BM}$ & 0.89 & 0.56 & 22.7 & 0.14 \\
\hline PDTSDTTSe:PC ${ }_{71} \mathrm{BM}$ & 0.78 & 0.80 & 22.9 & 0.20 \\
\hline
\end{tabular}

Abbreviations: FF, fill factor; $J_{\mathrm{sc}}$, short-circuit current density; PCE, power conversion efficiency; $V_{o c}$, open-circuit voltage.

avalues in the parentheses are averages of 6-9 devices.

Table 2 Optical and electrochemical properties of the polymers

\begin{tabular}{|c|c|c|c|c|c|c|c|c|c|}
\hline \multirow[b]{3}{*}{ Polymers } & \multicolumn{3}{|c|}{ UV-vis absorption spectra } & & & & & & \\
\hline & \multicolumn{2}{|c|}{$\lambda_{\max }(n m)$} & \multirow{2}{*}{$\begin{array}{c}\lambda_{\text {onset }}(\mathrm{nm}) \\
\text { Film }^{\mathrm{b}}\end{array}$} & \multicolumn{6}{|c|}{ Cyclic voltammetry } \\
\hline & Solution ${ }^{\mathrm{a}}$ & Film ${ }^{b}$ & & $\mathrm{E}_{g}^{o p t}(\mathrm{eV})^{\mathrm{c}}$ & $E_{\text {onset }}^{\text {ox }}(V)$ & $\mathrm{E}_{\text {onset }}^{\text {red }}(V)$ & HOMO (eV) & LUMO (eV) & $E_{g}^{e c}(e V)^{d}$ \\
\hline PBDTDTTSe & 402,473 & 409,487 & 609 & 2.04 & 0.71 & -1.62 & -5.51 & -3.18 & 2.33 \\
\hline PDTSDTTSe & 499 & 495 & 620 & 2.00 & 0.70 & -1.51 & -5.50 & -3.29 & 2.21 \\
\hline
\end{tabular}

Abbreviations: HOMO, highest occupied molecular orbital; LUMO, lowest unoccupied molecular orbital.

a Measured in chloroform solution.

bCast from chloroform solution.

${ }^{C}$ Calculated from the absorption onset of the films, $E_{\mathrm{g}}^{\mathrm{opt}}=1240 / \lambda_{\text {onset }}$.

${ }^{\mathrm{d}}$ Calculated from $E_{\mathrm{g}}^{\mathrm{ec}}=e\left(E_{\text {onset }}^{\mathrm{ox}}-E_{\text {onset }}^{\mathrm{red}}\right)$.

\section{SUMMARY}

We have successfully synthesized the thienoselenadiazole unit through the condensation reaction between thiophene diamine and $\mathrm{SeO}_{2}$ and applied the thienoselenadiazole unit for D-A-conjugated polymers. The thienoselenadiazole-based polymers, PBDTDTTSe and PDTSDTTSe, exhibit good solubility in common organic solvents, good thermal stability and deep HOMO levels. The solar cells based on thienoselenadiazole-containing polymers gave high $V_{\mathrm{oc}}$. Further improving of the light-absorption properties of the thienoselenadiazole-containing polymers to achieve high $J_{\mathrm{sc}}$ and high PCEs is currently underway.

\section{ACKNOWLEDGEMENTS}

This work was supported by the ' 100 Talents Program' of the Chinese Academy of Sciences. Funding from Suzhou Jiahong Optoelectronics and the Ministry of Science and Technology of China are greatly appreciated. We also thank Professor Jinsong Zhu for gifting a MBRAUN glovebox and Professor Zhong Zhang for kindly providing lab space.

1 Tang, C. W. Two-layer organic photovoltaic cell. Appl. Phys. Lett. 48, 183-185 (1986).

2 Yu, G., Gao, J., Hummelen, J. C. \& Heeger, A. J. Polymer photovoltaic cells: enhanced efficiencies via a network of internal donor-acceptor heterojunctions. Science 270, 1789-1791 (1995).

3 Li, G., Shrotriya, V., Huang, J. S., Yao, Y., Moriarty, T., Emery, K. \& Yang, Y. Highefficiency solution processable polymer photovoltaic cells by self-organization of polymer blends. Nat. Mater. 4, 864-868 (2005).

4 Cheng, Y. J., Yang, S. H. \& Hsu, C. S. Synthesis of conjugated polymers for organic solar cell applications. Chem. Rev. 109, 5868-5923 (2009).

5 Tsai, J. H., Lee, W. Y., Chen, W. C., Yu, C. Y., Hwang, G. W. \& Ting, C. New two-dimensional thiophene-acceptor conjugated copolymers for field effect transistor and photovoltaic cell applications. Chem. Mater. 22, 3290-3299 (2010).

6 Hou, J. H., Chen, H. Y., Zhang, S. Q., Chen, R. I., Yang, Y., Wu, Y. \& Li, G. Synthesis of a low band gap polymer and its application in highly efficient polymer solar cells. J. Am. Chem. Soc. 131, 15586-15587 (2009).

7 Chu, T. Y., Lu, J. P., Beaupré, S., Zhang, Y. G., Pouliot, J. R., Wakim, S., Zhou, J. Y., Leclerc, M., Li, Z., Ding, J. F. \& Tao, Y. Bulk heterojunction solar cells using thieno [3,4-c]pyrrole-4,6-dione and dithieno[3,2-b:2', $3^{\prime}$-d]silole copolymer with a power conversion efficiency of 7.3\%. J. Am. Chem. Soc. 133, 4250-4253 (2011).

8 Chen, Y. C., Yu, C. Y., Fan, Y. L., Hung, L. I., Chen, C. P. \& Ting, C. Low-bandgap conjugated polymer for high efficient photovoltaic applications. Chem. Commun. 46 , 6503-6505 (2010).

9 Zhang, Y., Chien, S. C., Chen, K. S., Yip, H. L., Sun, Y., Davies, J. A., Chen, F. C. \& Jen, A. K. Y. Increased open circuit voltage in fluorinated benzothiadiazole-based alternating conjugated polymers. Chem. Commun. 47, 11026-11028 (2011).

10 Zhang, Y., Zou, J. Y., Yip, H. L., Sun, Y., Davies, J. A., Chen, K. S., Acton, O. \& Jen, A. $\mathrm{K}$. Y. Conjugated polymers based on $\mathrm{C}, \mathrm{Si}$ and $\mathrm{N}$-bridged dithiophene and thienopyrroledione units: synthesis, field-effect transistors and bulk heterojunction polymer solar cells. J. Mater. Chem. 21, 3895-3902 (2011).

11 Wienk, M. M., Turbiez, M., Gilot, J. \& Janssen, R. A. J. Narrow-bandgap diketo-pyrrolopyrrole polymer solar cells: the effect of processing on the performance. Adv. Mater. 20, 2556-2560 (2008).

12 Chen, H. Y., Hou, J. H., Zhang, S. Q., Liang, Y. Y., Yang, G. W., Yang, Y., Yu, L. P., Wu, Y. $\& \mathrm{Li}, \mathrm{G}$. Polymer solar cells with enhanced open-circuit voltage and efficiency. Nat. Photonics. 3, 649-653 (2009).

13 Hou, J. H., Chen, T. L., Zhang, S. Q., Chen, H. Y. \& Yang, Y. Poly[4,4-bis(2ethylhexyl)cyclopenta[2,1-b;3,4-b']dithiophene-2,6-diyl-alt-2,1,3-benzoselenadiazole4,7-diyl], a new low band gap polymer in polymer solar cells. J. Phys. Chem. C. 113, 1601-1605 (2009).

14 Amb, C. M., Chen, S., Graham, K. R., Subbiah, J., Small, C. E., So, F. \& Reynolds, J. R. Dithienogermole as a fused electron donor in bulk heterojunction solar cells. J. Am. Chem. Soc. 133, 10062-10065 (2011).

15 Chen, Z. Y., Lemke, H., Seifried, S. A., Caironi, M., Nielsen, M. M., Heeney, M., Zhang, W. M., McCulloch, I. \& Sirringhaus, H. High mobility ambipolar charge transport in polyselenophene conjugated polymers. Adv. Mater. 22, 2371-2375 (2010).

16 Ha, J. S., Kim, K. H. \& Choi, D. H. 2,5-Bis(2-octyldodecyl)pyrrolo[3,4-c]pyrrole-1,4$(2 \mathrm{H}, 5 \mathrm{H})$-dione-based donor-acceptor alternating copolymer bearing $5,5^{\prime}$-di(thiophene2-yl)-2,2'-biselenophene exhibiting $1.5 \mathrm{~cm}^{2} \cdot \mathrm{V}^{-1} \cdot \mathrm{s}^{-1}$ hole mobility in thin-film transistors. J. Am. Chem. Soc 133, 10364-10367 (2011).

17 Mikroyannidis, J. A., Tsagkournos, D. V., Sharma, S. S., Vijay, Y. K. \& Sharma, G. D. Low band gap conjugated small molecules containing benzobisthiadiazole and thienothiadiazole central units: synthesis and application for bulk heterojunction solar cells. J. Mater. Chem. 21, 4679-4688 (2011).

18 Huo, L. J., Hou, J. H., Chen, H. Y., Zhang, S. Q., Jiang, Y., Chen, T. L. \& Yang, Y. Bandgap and molecular level control of the low-bandgap polymers based on 3,6-dithiophen-2-yl-2,5-dihydropyrrolo[3,4-c]pyrrole-1,4-dione toward highly efficient polymer solar cells. Macromolecules 42, 6564-6571 (2009).

19 Qian, G., Abu, H. \& Wang, Z. Y. A precursor strategy for the synthesis of low band-gap polymers: an efficient route to a series of near-infrared electrochromic polymers J. Mater. Chem. 21, 7678-7685 (2011).

20 Fernandes, J. A., Morisaki, Y. \& Chujo, Y. Aromatic-ring-layered polymers composed of fluorene and xanthenes. Polym. J. 43, 733-737 (2011).

Supplementary Information accompanies the paper on Polymer Journal website (http://www.nature.com/pj) 